\title{
1. Complexity in international trade and WTO law's legitimacy crisis
}

\subsection{THE BOOK'S PREMISE}

At the time of authoring this book, there was one threat to the WTO's dispute settlement system, the most praised element of the WTO, ${ }^{1}$ that was most pressing: the Appellate Body (AB) has been paralysed for over a year, its retiring members not having been replaced for years. As quorum cannot be attained, the $\mathrm{AB}$ cannot hear any appeals and a parallel system of appeals has been established by certain WTO Members. ${ }^{2}$

In essence, the $\mathrm{AB}$ paralysis is a crisis of legitimacy that has been years in the making. With the output of the WTO as a forum of trade negotiations impaired by the inability to conclude successfully the Doha Round, the WTO dispute settlement system has been under considerable strain for some time. Even before the $\mathrm{AB}$ was left without $\mathrm{AB}$ members, disputes had to be put on hold because of lack of personnel at the Secretariat; ${ }^{3}$ some disputes dragged on significantly over time and the circulation of Reports was being constantly postponed. The AB was missing the - admittedly very tight - deadlines set by Article 17.5 Dispute Settlement Understanding (DSU). WTO Members disagree as to the right course of action in these cases. ${ }^{4}$ The competence of $\mathrm{AB}$ members has been questioned. ${ }^{5}$ Mutually agreed solutions are on the rise, arguably because they offer a better and more efficient solution to disputing

\footnotetext{
1 G Sacerdoti et al, The WTO at Ten: The Contribution of the Dispute Settlement System (CUP, 2006).

2 Multi-party interim appeal arbitration arrangement pursuant to art 25 of the DSU, JOB/DSB/1/Add.12 (30 Apr 2020).

3 DSB, 'Statement by the DG Regarding Dispute Settlement Activities', WT/ DSB/M/350 (21 Nov 2014), 2-11; R Azevêdo, Speech of 28 Oct 2015 before the DSB, available at wto.org/english/news_e/spra_e/spra94_e.htm.

4 G Sacerdoti, 'The Increase in the Number, Length, and Complexity of Disputes and its Impact on the Workings of the Dispute Settlement System' in G Sacerdoti (ed.), 'The WTO Dispute Settlement System in 2014' (2014) XXIV Italian YIL 395, 396-8.

5 G Shaffer et al, 'The Extensive (but Fragile) Authority of the WTO AB' (2015) Arizona Legal Studies Discussion Paper No. 15-17; Sacerdoti (n 4) 399-400.
} 
Members. These raise important systemic issues with implications for the dispute settlement system's legitimacy. ${ }^{6}$ Attempts to reform the system are deadlocked.

These developments can partly be explained by the much more complex character of international trade - and by extension trade law - in the last ten years, compared to 1994 when the Uruguay Round was completed. Since tariffs are already very low, emphasis is placed on removing increasingly complex and sophisticated regulatory barriers. Complexity is a factor that manifests also in the disputes at the WTO's docket, through a dramatic increase in the number of measures challenged and claims made by dispute, an inevitable increase in the length of Reports, and an upsurge in the amount of submitted evidence. ${ }^{7}$ Thus, the concerns of legitimacy can be partly explained by the increasingly complex assessments, economic and otherwise, that WTO adjudicators have been called on to make.

Academia and practitioners alike have almost universally been calling for a more economic approach to various aspects of WTO law. ${ }^{8}$ WTO dispute settlement, after all, is expected to be more than the diplomatic settlement of disputes that permeated the GATT 1947, judicialised as that might have become. ${ }^{9}$ It is supposed to be more geared towards the rule of law, ensuring due process, leading to rational results, detached from the relative power of individual WTO Members. Following similar general trends in public interna-

6 M C Iacovides, 'Amicable Settlements, Mutually Agreed Solutions and Withdrawals in 2014: Is Compensation Displacing Compliance?', in Sacerdoti (n 4) 405-8.

7 Room Document circulated at the DSB, 'Annex to Director-General's Statement at the DSB Meeting of 28 Oct 2015', available at wto.org/english/news_e/news15_e/ dsbannex e.pdf.

8 E.g., D Neven, 'The Economic Evaluation of Protection under Art III' in T Cottier and P C Mavroidis, Regulatory Barriers and the Principle of Non-Discrimination in World Trade Law (Michigan UP, 2000); P C Mavroidis, 'Remedies in the WTO Legal System' (2000) 11 EJIL 763; W-M Choi, 'Like Products' in International Trade Law: Towards a Consistent GATT/WTO Jurisprudence (OUP, 2003); N Diebold, Non-Discrimination in International Trade in Services: 'Likeness' in WTO/GATS (CUP, 2010); C P Bown and J Pauwelyn (eds), The Law Economics and Politics of Retaliation in WTO Dispute Settlement (CUP, 2010); G M Grossman and A O Sykes, "'Optimal" Retaliation in the WTO' (2011) 10 WTR 133; C A Melischek, The Relevant Market in International Economic Law: A Comparative Antitrust and GATT Analysis (CUP, 2013).

9 G Marceau et al, 'Introduction and Overview' in G Marceau (ed.), A History of Law and Lawyers in the GATT/WTO: The Development of the Rule of Law in the Multilateral Trading System (CUP, 2015), 9-11; R E Hudec, Enforcing International Trade Law: The Evolution of the Modern GATT Legal System (Butterworth Legal Publishers, 1993). 
tional law, WTO law and dispute settlement is expected to possess and display the characteristics of natural sciences and economics, epistemologically coherent, verifiable by models.

Is the WTO dispute settlement system up to that task? Its legitimacy - and, given its importance, the legitimacy of the WTO - it seems, depends on it. The way to provide an answer to that question is not immediately obvious. How can legitimacy be measured and the effectiveness of the dispute settlement system and the WTO in achieving its aims be judged and verified? Testing this empirically is to a certain extent possible, ${ }^{10}$ but far from uncomplicated. Understandably, this is predominantly the work of economists. ${ }^{11}$

Yet, how would a lawyer approach this? For this author, it is clear that one has to look beyond the WTO to find solutions to ameliorate its legitimacy crisis, to a system of law that has had to deal with very similar problems and in many ways is still doing so, competition law.

Looking towards competition law is not unique or innovative. ${ }^{12}$ Yet, beyond a piecemeal comparison with competition law, it is submitted that one has to take a much more macro-perspective than has hitherto been adopted in the relevant scholarship. That is to say, we need to go beyond a mere focus on individual aspects of the system, by looking at WTO law and dispute settlement as holistically as possible. In this author's view, the WTO needs to have a coherent 'worldview' (weltanschauung) in its adoption of economics.

\subsection{THE BOOK'S APPROACH}

Driven by an interest in WTO law and competition law, armed with unstructured empirical observations from both systems and a desire to explain similarities and differences, and wanting to provide normative guidance to make

10 E.g., C P Bown and K M Reynolds, 'WTO Trade Disputes, Big and Small', available at voxeu.org/Art/wto-trade-disputes-big-and-small; C P Bown, Self-enforcing Trade: Developing Countries and WTO Dispute Settlement (Brookings Institution Press, 2009) 240; A Huneeus, 'Compliance with Judgments and Decisions', in C Romano et al (eds), The Oxford Handbook of International Adjudication (OUP, 2014); W J Davey, 'Evaluating WTO Dispute Settlement: What Results Have Been Achieved Through Consultations and Implementation of Panel Reports?' in Y Taniguchi et al (eds), The WTO in the Twenty-First Century: Dispute Settlement, Negotiations, and Regionalism in Asia (CUP, 2007).

${ }_{11}$ See e.g., C P Bown and K M Reynolds, 'Trade Flows and Trade Disputes', World Bank Policy Research Working Paper 6979 (July 2014).

12 D Unterhalter, 'Is Legal Reasoning Distinct from Economic Reasoning in WTO Law', Plenary Keynote Speech at the Society of International Economic Law Biannual global conference (Berne, July 2014), personal notes (on file with the author). See also, works cited supra $\mathrm{n} 8$. 
improvements to WTO law provided impetus and inspiration for this book. The epistemological reasons for looking at $E U$ competition law are explored further below; suffice it to say here that EU internal market law and, thus, EU law in general, have been modelled on GATT principles. ${ }^{13}$ The anecdotal observations that give context to the choice to compare WTO law with EU competition law are several similar developments in the two legal systems and a few divergences. The most important similarity is the development and relatively successful implementation of a so-called 'more economic approach' to EU competition law from the 1990s and onwards and the analogous, yet more recent, more 'scientific' and judicial approach to WTO law. This has brought increased complexity in both systems and has subjected them to similar calls to increase capacity and integrate economics correctly. It has also given rise to similar scepticism as to the benefits of the more economic approach, many of which shared by this author. As to divergences, in EU competition law, the adoption of a more economic approach has been holistic, even if gradual, whereas in WTO law it is focused mostly on 'likeness' and to a lesser extent on the estimation of permissible retaliation. Quantification has not caught on in other aspects of WTO law. In EU competition law, economists are well integrated in the workings of DG Competition. In WTO law there is some ad hoc integration of economists as liaison officers in some disputes where it is apparent they are needed, but not much more than that. Most panellists are trade diplomats or lawyers, and little economic expertise exists in the dispute settlement divisions. In contrast to EU competition law, in WTO law there seems to be obstacles hampering proper communication between economists and lawyers. ${ }^{14}$

As the book has its origins in unstructured empirical observations as the ones set out above, its approach is predominantly bottom-up, inductive reasoning. Through the application of a specific - and in this field unique - method that uses law and economics comparatively, the specific unstructured observations become organised and structured. Based on that, the research progresses to identify patterns relating to adopted benchmarks, to enable general and normative conclusions to be drawn. Those conclusions at times enlighten EU competition law's and occasionally both legal systems' performance; that said, they predominantly concern WTO law.

13 F Ortino, Basic Legal Instruments for the Liberalisation of Trade: A Comparative Analysis of EC and WTO Law (Hart Publishing, 2004).

${ }_{14}$ M C Iacovides and M Jansen, 'Lost in Translation: Communication and Interpretation Challenges Related to Economic Evidence in Trade Disputes', in T Carpenter et al (eds), The Use of Economics in Trade Disputes: Lessons Learned and Challenges Ahead (CUP, 2017). 


\subsubsection{Research Question}

The primary research question that this book provides an answer to can be formulated as follows:

Based on the findings of a comparative evaluation with EU competition law, has the adoption of a more economic approach to certain aspects of WTO law and dispute settlement made WTO law as administrable, efficient, and effective as EU competition law? What normative conclusions can be drawn from the comparison as to improvements that can be made to WTO law and dispute settlement in order to facilitate that system to achieve its objectives?

This question has not been addressed before, at least not with the broader scope and with this book's specific methodological approach.

As follows from the formulation of the primary research question, the book's aim is to evaluate the adoption of a more economic approach to WTO law and to provide normative conclusions. The aim is significant, since it has hitherto mostly been taken for granted that more economics in WTO law is a positive development. The premise surely sounds reasonable and in line with law's 'scientification'. Nonetheless, it cannot simply be assumed; compelling reasons need to be provided for it and those have to be verifiable. Thus, the underlying aim is to provide normative conclusions for WTO law's improvement and at the same time to establish the suitability of a more economic approach for the WTO on a solid theoretical foundation.

\subsubsection{Normative Comparative Law and Economics}

The method applied in this book is normative comparative law and economics. It is first and foremost concerned with the economic analysis of law, but synthetises that with a comparative method.

Law and economics, a paradigm-shifting movement at the divide of legal modernism and postmodernism, rose to prominence in the $1960 \mathrm{~s}^{15}$ as an expression of the belief that law, a social science, could be elevated to the status of natural sciences through the application of a distinctive legal method based on economics. ${ }^{16}$ Through law and economics, law's missing authority might be found by looking outside law, to a more precise and less subjective science, economics. Law could be epistemologically sound, neutral, an apolit-

15 R H Coase, 'The Problem of Social Cost' (1960) III JL\&E 1; G Calabresi, The Costs of Accidents: A Legal and Economic Analysis (Yale UP, 1970).

${ }_{16}$ G Minda, Postmodern Legal Movements: Law and Jurisprudence at Century's End (NYUP, 1995), 5. 
ical science based on reason. ${ }^{17}$ As such, it might also be empirically verifiable. Legal problems might be explained and illuminated by economics and the same could be done with policy choices and dispute adjudication. ${ }^{18}$ Models could be created to test, verify, or discredit different solutions.

Law and economics makes a few fundamental claims adhered to in varying degrees by different schools. In this book, I adopt the normative claim of law and economics, i.e., that the law ought to be efficient, and I adhere to the genetic claim with regard to both competition and WTO law, i.e., that the law tends to select efficient rules, although not every rule will, at any given time, be efficient. ${ }^{19}$

There are two important concepts that provide background to any work in law and economics, including this book. These are maximisation (of utility, wealth, or some other preferred value) and efficient equilibrium. Maximisation conceptualises the idea that the goal of rational individuals and companies is to maximise their utility. ${ }^{20}$ The second concept expresses the belief that competitive markets tend toward an efficient allocation of resources. ${ }^{21}$ Efficient is that which gives maximum output from a given input, or a given output with the minimum input. ${ }^{22}$

Law and economics is not without its opponents, internal and external. The external criticism focuses on what is perceived as the colonisation of law by economics. ${ }^{23}$ The internal criticism accepts the logic of economic analysis of law, but challenges certain assumptions. To the extent relevant for the analysis and discussion undertaken in this book, account has been taken of various criticisms to law and economics as a method.

Comparative law is concerned with the comparison of different legal systems. The presentation of two legal systems side by side, or the knowledge

17 But contrast the assertion that economic science has an ideology, classical liberalism: J M Buchanan, 'The Soul of Classical Liberalism' (2000) V:1 The Independent Review 111.

18 For a comprehensive coverage, see R A Posner, Economic Analysis of Law (9th edn.; Wolters Kluwer, 2014).

19 L A Kornhauser, 'The Great Image of Authority' (1984) 36:1-2 Stanford LR 349, 353-5.

20 For an overview: R A Posner, 'Utilitarianism, Economics, and Legal Theory' (1979) 8 Journal of Legal Study 103.

${ }_{21}$ A Smith, An Inquiry into the Nature and Causes of the Wealth of Nations (5th edn.; Methuen \& Co., 1904), book IV, ch II, para 9.

22 Efficiency is a complex concept that can be understood in different ways (e.g. Pareto efficiency, Kaldor-Hicks efficiency, etc.). In comparative law and economics no precise definitions of key concepts have to be adopted.

${ }^{23}$ R D Cooter, 'Law and the Imperialism of Economics: An Introduction to the Economic Analysis of Law and a Review of the Major Books' (1981) 29 UCLA Law Review 1260. 
of two systems does not suffice for proper comparison, as the endeavour must have some direct utility. ${ }^{24}$ That utility is the 'improvement which is made possible in one legal system as a result of the knowledge of the rules and structures of another'. ${ }^{25}$ Comparative law can explain how legal change happens through the phenomenon of legal transplants. ${ }^{26}$ Countering determinism, ${ }^{27}$ a comparative approach shows that legal rules are not bound to social structures, but operate instead on the level of ideas ${ }^{28}$ and that law does not reflect totally the society in which it operates, since much of it is borrowed. ${ }^{29}$

Comparative lawyers were explaining legal transplants mostly on grounds of 'prestige', i.e., that when confronted with a legal problem, a system will tend to turn towards a more developed system, as its solution will have a recognised pedigree. The synthesis of comparative law with law and economics offered an alternative explanation to prestige that had more appeal in the brave new world of economic analysis of law. That alternative explanation was none other than efficiency. ${ }^{30}$ Thus, transplants provide methodological context and illuminate how and why law and economics can be combined with comparative law.

Comparative law and economics is often categorised as a 'third generation of comparative law'. ${ }^{31}$ The method can be used to achieve what comparative law can achieve, while additionally offering an alternative explanation to legal change and a way to verify the soundness of legal change. Thus, it can provide a more robust normative dimension to comparative law.

In this book, I adopt a comparative law and economics method, by progressing from the positive de lege lata to the normative de lege ferenda. Thus, at the macro level of procedure, I describe the adoption and application of a more economic approach to EU competition law and to WTO law holistically, while zooming in at the micro level to describe how specific legal problems have been solved (or could have been solved) by adopting an economic approach. The description is then used to explain why the two legal systems are similar in certain aspects and diverge in others. ${ }^{32}$ That explanation ought also to have pre-

\footnotetext{
24 M Bogdan, Comparative Law (Nordsteds Juridik, 1994), 57.

25 A Watson, 'Comparative Law and Legal Change' (1978) 37:2 The Cambridge LJ $313,317$.

26 A Watson, 'The Birth of Legal Transplants' (2012-2013) 41:3 Georgia Journal of International and Comparative Law 605.

27 Montesquieu, De L'Esprit des Lois (1748), book I, ch 3.

28 A Watson, Society and Legal Change (2nd edn.; Temple UP, 2001), 130.

29 Watson, 'The Birth of Legal Transplants' (n 26) 607.

30 U Mattei, Comparative Law and Economics (Michigan UP, 1997), 125-45.

31 G De Geest and R Van Den Bergh, 'Introduction', in G De Geest and R Van Den Bergh (eds), Comparative Law and Economics (Edgard Elgar, 2004), xi.

32 J Gordley, 'The Functional Method' in G Monateri (ed.) Methods of Comparative Law (Edward Elgar, 2012), 107.
} 
dictive force: it might point to future areas of convergence and of divergence. Finally, in case of variety, the normative element of the comparative law and economics method allows me to evaluate which solutions are optimal for WTO law, judged from the chosen perspective and benchmarks. ${ }^{33}$

Hence, the book's overarching method can be summarised as describing, explaining, predicting, evaluating, and suggesting. It explores in great detail a number of solutions and arrangements in EU competition law, takes them as a benchmark, evaluates how WTO law measures up to that benchmark, suggests legal changes and optimal rules, and predicts further developments.

\subsubsection{Benchmarks}

There are various benchmarks in relation to which one can assess whether WTO law would fare better by adopting a more economic approach to the interpretation of its substantive rules and in the settlement of disputes, fashioned on EU competition law. This book is broadly concerned with coherence, consistency, accessibility, capacity, legal certainty, specialisation, legitimate expectations, effectiveness, predictability, and possible effects of judicial mistake. These are largely interwoven - think of them like a patchwork kilim rug of benchmarks, covering the book's ground. One can choose to focus on one of the square patterns individually, see them as a whole, or abstract from them to find what they share in common.

In effect, a great deal of their common core is about administrability, 'the need for simple rules that any judge can administer without having to deal with complex economic matters' ${ }^{34}$ The concept, which had a pivotal place in the Harvard school of economics, emphasises clarity, repose, and - influenced by Coase - the reduction of transaction costs. ${ }^{35}$ The benchmarks can also be aggregated as effectiveness, in the sense of relative success in and contribution to promoting the aims of the dispute settlement system and the WTO, or even loosely as efficiency, in the sense of efficient settlement of disputes and administration of the rules. If the aims are economic efficiency and ultimately (consumer) welfare, then we also have a nexus here between the goals and the method, bridging efficiency and effectiveness with law's economic analysis.

33 M Andenas and D Fairgrieve, 'Intent on Making Mischief: Seven Ways of Using Comparative Law', in Monateri (32) 29.

34 P Akman, The Concept of Abuse in EU Competition Law: Law and Economic Approaches (Hart Publishing, 2012), 289.

35 E.g., P Areeda, 'Monopolization, Mergers, and Markets: A Century Past and the Future' (1987) 75:3 California LR 959, 965-70; WE Kovacic, 'The Intellectual DNA of Modern US Competition Law for Dominant Firm Conduct: The Chicago/Harvard Double Helix' (2007) 1:1 Columbia Business LR 1, 14, 36-7, and 79. 
Having a comparative law and economics approach largely removes the necessity of having to make a definite choice as to the strand of law and economics we should adhere to and the ultimate benchmarks to use. In other words, the notions of efficiency, effectiveness, and administrability that are utilised in this book are comparative. ${ }^{36}$ In comparative law and economics, it is more important that the comparators are evaluated against the same benchmark, than what the exact meaning of that benchmark is.

\subsubsection{Why This Unique Approach?}

The choice to utilise the tools of the comparatists together with those of law and economics is motivated by the added value of the method in terms of explanatory power, prescription, and normativity. ${ }^{37}$ The comparator legal system, in our case EU competition law, becomes a 'huge library of reported legal experiments'. ${ }^{38}$ Conclusions drawn from its experience with similar WTO problems can be extrapolated to WTO law. Its amassed knowledge can teach WTO law a lot, especially on the institutional and procedural levels, which do not depend on the specificities of substantive rules. Thus, the particular method chosen in this book helps us 'identify those aspects of the system that stand in the way of the reception of an efficient legal solution' and enables us to 'foresee long-term efficiency consequences of a given legal arrangement that are impossible to identify if we do not employ comparative methods' ${ }^{39}$ This is what the normative comparative parts of this book do. Mimesis may be a better transformative method than reinventing the wheel.

Other studies in this field have focused on the more economic approach to WTO law, but only at the intersection where the definition of the relevant market converges with 'likeness' ${ }^{40}$ The method applied has not been explicitly comparative and, in any case, not normative comparative law and economics. When it comes to the broader comparisons of the two systems - a prolific genre - the method adopted is 'pragmatic and relaxed'41, i.e., quite different from the one espoused here. Additionally, the studies that compare WTO law with competition law do not establish the latter's supremacy. Instead, competition law's approach is taken as a priori satisfactory without much discussion, problematisation, or critical thinking. This book's approach, on the contrary, is

\footnotetext{
Mattei (n 30) 2.

De Geest and Van Den Bergh (n 31), xvii.

Ibid.; Ortino (n 13) 5.

Mattei (n 30) 145.

See supra, $\mathrm{n} 8$.

41 Ortino (n 13) 6 and fn 17.
} 
to establish first what the real law and economics benchmark is vis-à-vis which WTO law is evaluated.

In sum, the choice of method for this book is motivated by a consideration of the added value it can provide in terms of originality, scope, explicative power, and normativity. It enables a satisfactory answer to the formulated research question to be provided and to do so from a unique point of view that has not been adopted previously.

\subsubsection{Tertium Comparationis}

Trade law is in essence economic law and, like competition law, it has been subject to economic analysis. ${ }^{42}$ Trade law, like competition law, adheres to the organising ideas of profit maximisation, rationality, and economic equilibrium that are typical of a law and economics method. Just like in competition law, economics provides a framework allowing the observance of trade law and enjoys hermeneutic power. ${ }^{43}$ Economics can also operate on the normative level in trade law.

The choice of competition law as comparator for WTO law is further motivated by common characteristics that make them easily comparable: they have similar ideological and historical underpinnings and they share common objectives. ${ }^{44}$ Moreover, there is a significant volume of scholarship comparing WTO law with competition law to tap into.

What about the epistemological reasons for choosing specifically $E U$ competition law as comparator? EU law and WTO law 'have common roots in economic theory and associated legal principles' ${ }^{45}$ The EU is an important and influential actor in WTO law. ${ }^{46}$ The EU and the WTO also share a great deal of their substantive rules ${ }^{47}$ Both are treaty-based. Functional similarities

42 E A Posner and A O Sykes, Economic Foundations of International Law (Harvard UP, 2013), chs 3 and 18.

43 A van Aaken, 'Opportunities for and Limits to an Economic Analysis of International Law' (2011) 3:1 Transnational Corporations Review 27, 43.

44 Infra, s 1.2.6.

45 SE Gaines et al, 'Comparing Two Trade Liberalisation Regimes', in SE Gaines et al (eds.), Liberalising Trade in the EU and the WTO: A Legal Comparison (CUP, 2012), 6 .

${ }^{46}$ P Holmes, 'The WTO and the EU: Some Constitutional Comparisons', in G De Búrca and J Scott (eds.), The EU and the WTO: Legal and Constitutional Issues (Hart Publishing, 2001), 79; T Krüger, 'Shaping the WTO's institutional evolution, the EU as a strategic litigant in the WTO', in D Kochenov and F Amtenbrink, The EU's Shaping of the International Legal Order (CUP, 2013), 169-90

47 Holmes (n 46) 79; Ortino (n 13) 3. 
also exist in the two organizations' judiciary branches. ${ }^{48}$ EU competition law is a representative paradigm of competition law, borrowed as it has done from other jurisdictions, while also providing inspiration for competition law systems in Europe and globally. EU competition law is situated in a broader context where it is not simply a system of competition law, but also part of a system establishing an internal market and dealing with trade rules.

Despite these similarities, the two systems are not identical substantially and procedurally. Comparison is nevertheless possible on a functional level, i.e., when aspects of the two systems that have the same functions are compared. ${ }^{49}$ Thus, beyond the idiosyncrasies of the two systems, functional comparison allows a common denominator, a tertium comparationis, to be found. This is always clearly demarcated in the book's comparative chapters and specific sections are dedicated to establishing functional comparability.

\subsubsection{Objectives of EU Competition Law and WTO Law}

The objectives of the compared legal systems are important for adequately answering the research question, as the adoption of a more economic approach is evaluated by its effectiveness in furthering those objectives. Comparative evaluation, i.e., normative comparison, can only be made if the objectives of the compared systems can be reasonably assumed to be identical or similar. ${ }^{50}$

An exhaustive, detailed, and systematic survey into EU competition law case law and decisional practice from the 1960s to 2020 conducted by Iacovides and Stylianou shows - consistently with other positive and normative research - that EU competition law pursues a plethora of goals. ${ }^{51}$ Many of those can be traced back to the EU's overarching goals, found in Article 3 TEU. That said, the Commission's move towards a more economic approach ${ }^{52}$ has in many

48 B Marchetti, 'EU and Global Judicial Systems', in E Chiti and BG Mattarella (eds), Global Administrative Law and EU Administrative Law: Relationships, Legal Issues and Comparison (Springer, 2011), 47-8; J H H Weiler, 'The Constitution of the Common Market Place', in P Craig and G De Búrca (eds), The Evolution of EU Law (OUP, 1999), 34 ff.

${ }^{49} \mathrm{~K}$ Zweigert and H Kötz, Introduction to Comparative Law (3rd edn.; OUP, 1998), 34 .

50 A Bakardjieva Engelbrekt, Fair Trade in a Flux? National Legacies, Institutional Choice and the Process of Europeanisation (Stockholm University, 2003), 68.

${ }_{51}$ K Stylianou and M C Iacovides, 'Goals of EU Competition Law-A Comprehensive Empirical Investigation', available at https://ssrn.com/abstract=3735795, accessed 13 May 2021.

52 White Paper on the Modernisation of the Rules Implementing Articles 85 and 86 of the EC Treaty [1999] OJ C132/1. 
ways subsumed those goals under the consumer welfare goal, although that is constitutionally questionable as argued by Iacovides and Vrettos. ${ }^{53}$

What about the objectives of WTO law? The Preambles to the WTO Agreement and the GATT 1994 set broad goals, such as development, increasing standards of living, employment, growth etc. ${ }^{54}$ These are in line with those of the EU, as expressed in Article 3 TEU. The transposition of the goals into legal rules is done predominantly through a non-discrimination model and the avoidance of protectionism, understandably given the classical origins of trade law. ${ }^{55}$ Trade restrictions such as tariffs and quotas are seen as inefficient compared to letting the market uninhibited, to reach an equilibrium. ${ }^{56}$ Reaching an efficient equilibrium necessitates equalising the conditions for competition, something that in its turn creates a need to have non-discriminatory trade rules in place and ensure the elimination of protectionism. This finds expression in the most-favoured nation (MFN) principle and the national treatment principle, principles which operate as the Dioscuri of WTO on two different, yet parallel, axes, together ensuring that no discrimination occurs on trade in goods and services between Members. They permeate all the WTO covered agreements covered in this book. Together, the two principles ensure fair competition on the merits, remove market distortions, and lead to an effective recourse allocation; all to the benefit of consumers.

Therefore, WTO law and EU competition law have corresponding ultimate objectives, even if this is not always appreciated when one focuses on differences in process, i.e., how to arrive at the same desired result, rather than in substance. ${ }^{57}$ Trade law achieves welfare through rules on non-discrimination, whereas competition law does the same through preserving a healthy degree of competition.

53 'Falling through the cracks no more? Article 102 TFEU and Sustainability I - The Nexus Between Dominance Environmental Degradation and Social Injustice' (2021) 9:3 Journal of Antitrust Enforcement (forthcoming), s 4.

54 ABR, US - Shrimp, para 153.

55 D Ricardo, Principles of Political Economic and Taxation (Createspace, 2010), 61-62; W M Corden, 'The Normative Theory of International Trade' (1984) 1 Handbook of International Economics 63, 63-130; A V Deardorff, 'The General Validity of the Law of Comparative Advantage' (1980) 88:5 Journal of Political Economy 941; cf D M Driesen, 'What is Free Trade? The Real Issue Lurking Behind the Trade and Environment Debate' (2000) 41:2 Virginia JIL 279, 341.

${ }^{56}$ A O Sykes, 'Comparative Advantage and the Normative Economics of International Trade Policy' (1998) 1 JIEL 49, 60.

57 PR, Korea - Alcoholic Beverages, para 7.4; PR, Chile - Alcoholic Beverages, para 7.87 . 


\subsubsection{Sources}

The cut-off date for the research undertaken to produce this book was 1 January 2021. The sources have been determined by the method and the scope. From EU competition law the main legal sources are primary law, especially Articles 101 and 102 TFEU and secondary law, most notably the EU Merger Regulation, the main implementing legislation Regulation $1 / 2003$, and the Directive on Competition Damages Actions. Case law from the CJEU and Commission decisional practice have been instrumental. Soft law has also been a significant source. Opinions of Advocate Generals of the Court have also been consulted, where this was useful to understand the case law. When it comes to academic opinion and studies, most of these are legal doctrine, but this being a study in comparative law and economics, some literature from economics has also been used.

From WTO law, the main sources of study have been six of the WTO covered agreements, namely the GATT, the GATS, the TBT, the SPS, the SCMA, and the ADA. The DSU, setting out as it does WTO dispute settlement's procedural law, has been instrumental. The case law from the dispute settlement system, in the form of panel and AB Reports and Decisions by arbitrators, is an important source. This book covers disputes relating to the six WTO covered agreements studied. Roughly, this covers 80 per cent of all claims made in requests for consultations. ${ }^{58}$ There are no significant secondary sources of WTO law and the academic opinion regarding WTO law that has been studied is mostly legal doctrine and economics.

\section{$1.3 \quad$ STRUCTURE}

Following this Part I, the rest of the book is divided in four parts.

Part II, entitled Defining the relevant market and 'Likeness', is concerned with the definition of the relevant market in EU competition law (Chapter 2) and 'likeness' in WTO law (Chapter 3). It also includes (in Chapter 4) a thorough comparison and evaluation of the two legal systems, regarding a more economic approach to 'likeness'.

Parts III and IV, entitled Proving Infringements: Theories of Harm and Effects and Quantifying Harm: Remedies and Sanctions respectively, broaden the perspective to offer a more holistic assessment of whether economic theory, analysis, and method, are desirable for WTO law.

58 V Hughes, 'Working in WTO Dispute Settlement - Pride Without Prejudice', in Marceau (n 9) 412, Fig 28.1. 
Part III looks at theories of harm and the effects-based approach in EU competition law (Chapter 5) and in WTO law (Chapter 6). The approaches are then compared (Chapter 7) and WTO law is evaluated according to the benchmark established for EU competition law.

Part IV deals with remedies and sanctions in the two systems, with EU competition law first (Chapter 8), followed by WTO law (Chapter 9). The two systems are again compared and WTO law is evaluated (Chapter 10).

In Part V, Chapter 11 takes stock of the findings from the comparative chapters in the three substantive parts and, based on a holistic appraisal of WTO law, makes normative suggestions for its improvement. Chapter 12 concludes the monograph with some general remarks and a road map for future research.

Different chapters demonstrate different aspects of the method. Some deal with competition law, some with WTO law, and some with both systems. For that reason, readers with substantial knowledge of one or the other system may find it convenient to bypass the descriptive parts of any of the two legal systems and focus instead on the comparative, analytical, and evaluative chapters. 